\title{
Francisco FERNÁNDEZ IZQUIERDO, Castell de Castells con la Orden de Calatrava. La encomienda de Bejís y Castell de Castells. Un reducto señorial en el Reino de Valencia durante la Edad Moderna, Madrid, Visión Libros, 2014. 145 pp. ISBN: 978- 84-16284-17-7
}

El autor del libro, Francisco Fernández Izquierdo (Madrid, 1959) es actualmente investigador científico del Centro de Ciencias Humanas y Sociales del CSIC. A lo largo de su trayectoria, son varias las líneas investigadoras a las que se ha dedicado: la aristocracia y el pensamiento político, la informática y nuevas tecnologías de la información dedicadas al ámbito de la documentación, la historia social y económica del poder, e incluso aspectos tan lejanos a la Edad Moderna como son las obras hidráulicas en los siglos XIX y XX. Esta obra, dedicada a la encomienda valenciana de Bejís y Castell de Castells, estaría enmarcada en el estudio de las órdenes militares, especialmente la de Calatrava, rama a la que ha dedicado numerosos estudios a lo largo de su carrera, empezando por su tesis doctoral en 1986. Vale la pena recordar en este punto que el libro se enmarca en el proyecto de investigación El papel de los mercados financieros y la gestión de negocios mercantiles en las economías de la Monarquía Hispánica, ca. 1550-1650 y que ha contado con el apoyo de la Diputación de Alicante para su publicación.

Las órdenes militares han sido un tema recurrente en la historiografía a lo largo de los años, tanto en el ámbito español como extranjero. Si nos ceñimos a lo que ocurrió en la Península Ibérica, la enorme extensión de los territorios que dominaron estas instituciones a lo largo de la Edad Media y Moderna han generado numerosos estudios acerca de su historia, evolución, organización, administración o la sociología de algunos de sus miembros, desde los maestres y comendadores hasta los caballeros de hábito. La novedad del presente libro radica en que la encomienda objeto de estudio, única en la provincia de Alicante, apenas había sido tratada por otros autores más allá del ámbito local. Con esta obra se saca del oscurantismo un nuevo rincón perteneciente a las órdenes militares hispánicas, concretamente a las posesiones calatravas valencianas, ya que aunque el libro pone su foco en la localidad alicantina de Castell de Castells, esta perteneció desde 1526 a una encomienda conjunta con la localidad castellonense de Bejís. Temporalmente, la obra abarca desde comienzos del siglo XVI hasta finales del siglo XVIII, si bien la relación nominal de comendadores se expande por un lado a las primeras décadas del siglo XV y por otro a comienzos del siglo XIX.

Para la redacción de la obra el autor ha consultado diferentes bibliotecas y archivos de entre los que destacan los centros documentales clásicos para el estudio de la Edad Moderna, como son el Archivo General de Simancas (AGS) y el Archivo Histórico Nacional 
(AHN). La base sobre la que se ha construido el libro es la documentación generada por el Consejo de Órdenes en sus actuaciones judiciales y administrativas, en particular las "visitas". Parte de los vacíos de información que dejan estas visitas han sido llenados con pleitos procedentes de la sección "Archivo de Toledo" del AHN. Todo ello junto a una completa y variada bibliografía que agrupa desde colecciones documentales y grandes obras de historia general hasta estudios sobre el reino de Valencia y una amplia gama de trabajos centrados en diferentes aspectos y territorios de órdenes militares. Además, se hace referencia a algunos restos patrimoniales, de los que se aportan fotografías. Este libro que aquí reseñamos es parte de un proyecto que no ha hecho sino empezar, y que tendrá su continuación en futuras obras, gracias en parte al empeño y apoyo del Ayuntamiento de Castell de Castells por sacar a la luz su historia.

La obra está estructurada en una introducción, tres capítulos, epílogo y anexos. En la introducción, Fernández Izquierdo hace un recorrido rápido por la historia de las órdenes militares hispánicas, marcando algunos hitos como la fundación de Calatrava en 1158 o la anexión de los maestrazgos por parte de la Corona a comienzos de la Edad Moderna. Ello sirve para poner en situación al lector sobre qué es una orden militar, cómo funciona y cuál fue, a grandes rasgos, su recorrido histórico. Analizado todo ello, da algunas pinceladas sobre la historia de la encomienda de Bejís y Castell de Castells a través de los mandatos de los diferentes comendadores. En este punto, el autor relaciona lo que estaba ocurriendo en el ámbito local con lo que pasaba en el ámbito nacional o internacional a través de las diferentes relaciones que los comendadores establecían con otros personajes, como puede ser el Príncipe de Éboli. Ello hace que el libro no se quede en la esfera de lo localista para buscar un sentido histórico más completo.

El siguiente capítulo se dedica al estudio de la encomienda en la primera mitad del siglo XVI. El autor hace toda una declaración de intenciones, poniendo de relieve el valor las visitas como fuente histórica. Tras explicar en qué consisten y sus posibilidades de explotación, empieza a recorrer la historia de la encomienda, sobre todo de la localidad de Castell de Castells, desde 1501. Fernández Izquierdo expone de forma ordenada los diferentes datos que aportan cada una de las visitas, como los que aparecen en diferentes interrogatorios o inventarios que son parte de esta fuente documental. Las visitas de 1514 y 1534 también son analizadas, destacándose en este caso el papel de los funcionarios que ejecutaban dichas visitas como "delegados de la Corona con intención de promover el bien público y la justicia, defendiendo a los vecinos de posibles abusos del comendador". Algunos de los temas tratados y que son dignos de mención son los diferentes conflictos que día a día había entre los vecinos, los comendadores y la orden; la situación de los moriscos o el problema de las incursiones berberiscas en un territorio tan proclive a ello. En el caso de la visita de 1534, se incluye la transcripción de esta, lo cual permite al lector comprobar de primera mano cómo se redactaban, con qué tono y estilo y qué temas se enfocaban con más ahínco.

La segunda mitad del Quinientos tiene un capítulo para sí sola. La redacción de este capítulo está marcada por la ausencia de visitas hasta la de 1590. Esa falta de documentación es suplida mediante otros fondos documentales del Consejo de Órdenes, que permiten estructurar esta segunda mitad del siglo XVI en los diferentes mandatos de cada comendador. El arrendamiento en terceros de la encomienda y las obras y reformas en el castillo de la localidad son los aspectos más destacados. También en 1590 se hizo una averiguación de las rentas de la encomienda para conocer la rentabilidad de esta entre 1585 y 1590, de la que el autor obtiene información, aparte de sobre los aspectos económicos, sobre aspectos sociológicos estudiando quiénes fueron los testigos interrogados. En este período se produce un intento de venta de la encomienda a un noble aragonés que no 
llegó a completarse. Acompañan al capítulo unas tablas sobre el valor de los bienes de la encomienda a lo largo del siglo XVI.

Los siglos XVII y XVIII se ven de una forma más somera, como introducción a la continuación de la investigación que Fernández Izquierdo ya anunciaba en las primeras páginas. En este capítulo se estudia la gran repercusión que tuvo la expulsión de los moriscos en Castell de Castells. La repoblación tras la expulsión de 1609, las obras que se proyectaban y no se acometían en edificios municipales como el castillo y el molino y la relación entre las condiciones de los habitantes y el inicio de la Segunda Germanía en 1693 son algunos de los aspectos que trata el autor. Los trámites para el acceso al cargo, el ceremonial para tomar posesión de la encomienda y los contratos de arrendamiento son otros de los aspectos tratados. Antes de terminar, se hace un paso rápido por el siglo XVIII, donde se destacan algunos hitos como la asignación de la encomienda a miembros de la familia real y la alta rentabilidad de esta, mediante diferentes gráficos y tablas. Concluye el autor con la certeza de que Bejís y Castell de Castells fue la encomienda más productiva de todas las que permanecieron como reductos señoriales en las órdenes militares en Valencia.

La obra finaliza con un epílogo en el que Fernández Izquierdo comenta la existencia de documentación privada en posesión de algunos vecinos que se podría sumar a la existente en los archivos regionales y generales para estudiar el siglo XIX. Además, deja abierta la cuestión de si las largas ausencias de los comendadores en sus territorios hacían que el señorío de órdenes fuera más liviano que el secular.

Con este libro, Francisco Fernández Izquierdo viene a llenar un vacío historiográfico que existía sobre esta región calatrava en el reino de Valencia. Aunque el estudio de las órdenes militares no es una novedad historiográfica, sí que hay algunos aspectos y zonas aún desconocidos. En una obra de lectura ágil, el autor lleva a un recorrido por la historia de esta encomienda levantina a lo largo del siglo XVI de una manera profunda, y de una forma más ligera por las otras dos centurias que componen la Edad Moderna. Es reseñable que en las primeras páginas se haga una explicación de lo que eran las órdenes militares en la Península Ibérica y cómo funcionaban para ilustrar así a los lectores más neófitos. Aunque en un principio este tipo de obras corran el riesgo de caer en lo localista, este no es el caso del libro que reseñamos, pues nunca se pierde de vista el contexto general a lo largo del devenir de los acontecimientos. Se trata pues de una obra no cerrada, pues es un libro que sólo supone el inicio de un proyecto más amplio sobre la historia de Castell de Castells que a buen seguro tendrá su continuación en un futuro no muy lejano.

Luis Escudero Escudero Universidad de Castilla-La Mancha 